\title{
CORRECTION
}

\section{Correction: Diatom genomes come of age}

\author{
Assaf Vardi, Kimberlee Thamatrakoln, Kay D Bidle and Paul G Falkowski*
}

\section{Correction}

After the publication of this minireview [1], we noted errors in the figures given in Table 1 and the text for the percentage of genome that is non-coding. The percentages should be $42 \%$ for Thalassiosira pseudonana and $45 \%$ for Phaeodactylum tricornutum (see Table 1 a corrected version of Table 1).

\section{Author Details}

Environmental Biophysics and Molecular Ecology Program, Institute of Marine and Coastal Sciences, Rutgers University, New Brunswick, NJ 08540, USA

Published: 4 June 2010

\section{References}

1. Vardi A, Thamatrakoln K, Bidle KD, Falkowski PG: Diatom genomes come of age. Genome Biology 2008, 9:245

2. Armbrust EV, Berges JA, Bowler C, Green BR, Martinez D, Putnam NH, Zhou S, Allen AE, Apt KE, Bechner M, Brzezinski MA, Chaal BK, Chiovitti A, Davis AK, Demarest MS, Detter JC, Glavina T, Goodstein D, Hadi MZ, Hellsten U, Hildebrand M, Jenkins BD, Jurka J, Kapitonov VV, Kröger N, Lau WW, Lane TW, Larimer FW, Lippmeier JC, Lucas S, et al:: The genome diatom Thalassiosira pseudonana: ecology, evolution, and metabolism. Science 2004, 306:79-86.

3. Bowler C, Allen AE, Badger JH, Grimwood J, Jabbari K, Kuo A, Maheswari U, Martens C, Maumus F, Otillar RP, Rayko E, Salamov A, Vandepoele K, Beszteri B, Gruber A, Heijde M, Katinka M, Mock T, Valentin K, Verret F, Berges JA, Brownlee C, Cadoret JP, Chiovitti A, Choi CJ, Coesel S, De Martino A, Detter JC, Durkin C, Falciatore A, et al:: The Phaeodactylum genome reveals the evolutionary history of diatom genomes. Nature 2008, 456:239-44.

doi: 10.1186/gb-2010-11-6-401

Cite this article as: Vardi et al., Correction: Diatom genomes come of age Genome Biology 2010, 11:401

Table 1: Comparison of the genome properties of Thalassiosira pseudonana and Phaeodactylum tricornutum genomes*

Thalassiosira pseudonana
32.4

Predicted genes

Introns

Number of chromosomes

$\mathrm{G}+\mathrm{C}$ content

Percentage of genome that is non-coding

ESTs in GenBank
Phaeodactylum tricornutum
11,776

10,402

8,169

33

About 47\%

About 48\%

About 45\%

${ }^{*}$ Data from $[2,3]$.

* Correspondence: falko@marine.rutgers.edu

Environmental Biophysics and Molecular Ecology Program, Institute of Marine and Coastal Sciences, Rutgers University, New Brunswick, NJ 08540, USA

Full list of author information is available at the end of the article

๑) 2010 BioMed Central Ltd. 